\title{
THE GOVERNMENT-BUSINESS RELATIONSHIP AND ECO-INNOVATION: EVIDENCE FROM CHINESE AUTOMOBILE INDUSTRY
}

\begin{abstract}
This study used 2017-2019 Chinese A-share-listed automobile manufacturing companies as research samples to analyse the impact of the government-business relationship on eco-innovation. We found that a healthy government-business relationship had a positive impact on enterprise eco-innovation. The mediating effects test verified that a healthy government-business relationship affected enterprise eco-innovation through financing constraints. In addition, managerial ownership significantly increased the positive impact of a healthy government-business relationship on enterprise eco-innovation. We also found that a healthy government-business relationship had a more substantial impact on enterprise eco-innovation in non-state-owned enterprises when considering corporate property rights. The study results provide empirical evidence for the influence of the government-business relationship on enterprise eco-innovation and deepen our understanding of eco-innovation in China's automobile manufacturing industry.
\end{abstract}

Keywords: government-business relationship, eco-innovation, managerial ownership, state ownership, financial constraints

\section{Introduction}

Under the influence of guanxi in the Chinese business context, entrepreneurs often have multiple roles. On the one hand, entrepreneurs need to innovate to stay competitive, and on the other hand, they are also good at maintaining relationships with the government. They need to engage in both productive activities and other non-productive activities, such as rent-seeking [1]. In general, in addition to regular work and leisure activities, entrepreneurs always engage in internal business activities and external guanxi maintenance activities. In the process of guanxi maintenance, one of the most important relationships is the one between enterprises and the government. In the case of a good relationship between the government and enterprises, the government often creates a healthy business environment for enterprises, such as a suitable property rights protection system, an effective contract enforcement mechanism, and a system to limit the abuse of government power. A healthy business environment that is established by a good

\footnotetext{
1 School of Business, Qingdao University, Qingdao 266071, China, email: gylyj1108@163.com, dongxiaotian4@163.com

${ }^{2}$ College of Business Administration, Henan Finance University, Zhengzhou 451464, China

${ }^{3}$ Department of International Economics and Trade, College of Commerce, Hebei University of Economics and Business, Shijiazhuang 050061, China, email: yancai2020@126.com

*Corresponding author: tengzhuoqi@hafu.edu.cn
} 
relationship between government and business enables enterprises to devote more time and energy to production and operation activities. In other words, a healthy relationship between government and business can help enterprises to operate better. In contrast, a negative relationship between government and business will result in the enterprises spending a lot of time and energy in lobbying the government for more privileged policies and gray income [2-4]. Therefore, in China, a healthy government-business relationship enables enterprises to gain a broader space for development and invest more time and money in beneficial business activities, among which, eco-innovation is an important part.

Eco-innovation occurs within the context of shared global challenges, including the need to separate growth from resource use, increasing the use of renewable energy sources, improving energy efficiency, and reducing carbon emissions [5]. In addition, the recognition and application of green innovation by the government, enterprises, and individuals are also important [6]. It tries to find solutions to systematically reduce the environmental impact of manufacturing, consumption, and disposal activities [7]. Eco-innovation is becoming more apparent in the manufacturing and consumption industries. Electric cars, which are an example of an innovative eco-friendly product, are attracting global attention. In addition, eco-innovation can act as an important tangible economic facilitator [8]. Eco-innovation is also becoming an increasingly important part of enterprise research and development and applications. Therefore, it is becoming significantly more important to explore the determinants of eco-innovation. As described above, the Chinese government-business relationship plays an important role in the development of enterprises. Given this background, we aimed to answer the following questions: Can the government-business relationship affect enterprises' investment in eco-innovation? What are the factors that play a role in this process?

This study used 2017-2019 Chinese A-share-listed automobile manufacturing companies as research samples to analyse the impact of the government-business relationship on eco-innovation in the Chinese context. We found that a healthy government-business relationship had a positive impact on enterprise eco-innovation. The mediating mechanism test verified that the government-business relationship affected enterprises' eco-innovation through financing constraints. In addition, managerial ownership significantly increased the positive impact of a healthy government-business relationship on enterprises' eco-innovation. We also found that a healthy government-business relationship had a more substantial impact on enterprises' eco-innovation in non-SOEs (state-owned enterprises) when considering corporate property rights.

This research made the following contributions: First, the research perspective of this article is novel in terms of examining the impact of the government-business relationship on eco-innovation. Second, we theoretically analyse the heterogeneous influence of managerial ownership and state ownership, empirically show the moderating effect of managerial ownership and state ownership, and reveal the relationship between the government-business relationship and eco-innovation. Third, we provide new empirical evidence for the study of eco-innovation and enrich the literature regarding the impact of the business environment on microenterprise decision making and behaviour. Fourth, East Asian countries, such as China, Japan, and South Korea, have similar histories and cultures [9]. More government intervention in the market and industry results in a closer relationship between the government and enterprises. Research on the government-business 
The government-business relationship and eco-innovation: evidence from Chinese automobile industry 543

relationship in the context of China may have universal guiding significance for other East Asian countries.

The remainder of this article is structured as follows. Section 2 reviews the prior literature and states the research hypotheses. Section 3 presents the research design, mainly introducing the data sources, sample selection, variable measurement, and empirical model establishment. Section 4 shows the results of the empirical analysis, including the descriptive statistics, correlation analysis, main regression analysis, and robustness test results. Section 5 presents the empirical results of the mediating effects tests. Section 6 provides the research conclusions and implications.

\section{Literature review and hypothesis development}

\section{Literature review}

Previous studies held the view that the business environment is "a comprehensive ecosystem of the external environment faced by enterprises" when they engage in entrepreneurship and other activities [10]. Based on the ecological perspective, the relationship between the government and enterprises (competition and cooperation) within this ecology can affect the innovation activity of enterprises [11]. According to this perspective, the relationships between a government and enterprises can be divided into three categories: commensal, symbiosis, and dominance. The complex interactions of competition and cooperation between government and market produce different commensal, symbiotic, or dominant relationships, which determine a series of activities of enterprises in the ecology. Previous studies have focused on three of these relationships the "invisible hand," the "helping hand," and the "predatory hand" [12] - which guide the understanding of the interactions between governments and markets. However, previous studies on the relationship between them focused on the impact of institutions, education, and financial policies on the development of enterprises [13], without providing a comprehensive evaluation of the relationship between government and business, thus failing to identify the interaction between the government and enterprises in more fields. The influence of this pluralistic and complex relationship on the innovation ability of enterprises remains unclear.

Since entering the 21 st century, "green," "innovation," "sustainable," and other terms occupy our lives. More specifically, in the business context, the OECD defines eco-innovation as "the implementation of new or significantly improved products (goods and services), processes, marketing methods, organizational structures, and institutional arrangements that, whether intentionally or unintentionally, result in an improvement in the environment as compared to relevant alternatives" [14]. As enterprises put more and more attention into eco-innovation, it is becoming an increasingly important field for enterprises. However, different academic circles have different understandings in different fields of the concept of enterprise eco-innovation. In management circles, eco-innovation refers to the production, application, or exploration of goods, services, production processes, organizational or management structures, or business methods that are unfamiliar to companies or users. The result is a reduction in environmental impacts, such as less pollution and less of a negative impact on the use of resources, compared to the corresponding alternatives $[15,16]$.

In subsequent studies, researchers further extended the concept of eco-innovation. Incorporating innovative and eco-friendly attributes into the design of new products reflects 
a company's positive orientation toward positive sustainability in new product development, rather than passively eliminating environmental problem characteristics [17]. The eco-innovation are referred as new products, processes, and practices that are designed to reduce or avoid environmental hazards, or modifications to existing products, processes, and practices [18]. Iyer and Reczek emphasised the development of eco-friendly creations in innovation (for example, the introduction of innovative recyclable materials), which is more in line with the current understanding of innovation [19].

Previous studies also focused their reviews on innovative management models $[20,21]$. Silva et al. conducted a comparative study on the classical models of innovation management to understand the modelling, stages, and organizational factors of the innovation process [20]. Cagnazzo et al. studied the major evolutions of innovation management models and discussed the forms and structures of these models by analysing their advantages and disadvantages [21]. In the field of innovation management, a study by Hidalgo and Alors focused on innovation in management techniques (rather than models) and review of the development, uses and trends [22].

The research on eco-innovation itself mainly focuses on three levels, namely, the motivation of innovation, performance, and the innovation process [23]. Motivation-related studies mainly explored the antecedent variables that influence innovation at different levels. These studies mainly included different motivational factors in the stages of adaptation, development, and under-innovation. For example, previous studies showed that technological capabilities, environmental organizational capabilities, market-based instruments, customer green demand, and competitive pressures can have an impact on enterprises' eco-innovation behaviours [24]. These studies mainly discussed the outcomes and outputs of innovations, including financial performance, competitive performance, and market performance. For example, previous studies mainly focused on cost-effectiveness [14], increasing productivity and reducing energy use or pollution [25], creating win-win situations that are characterised by both economic and environmental benefits [23], increasing sales [26], and improving brand positioning and brand image [27]. Another field of studies on eco-innovation focuses on the development process of different types of innovation, such as the process of eco-innovation in marketing.

However, in practice, organizations need guidance on how to systematically apply their efforts to achieve environmental goals and maintain continuous improvement in the environmental performance of their products and management processes [28]. Eco-innovation is the core part of enterprise activities, so that the enterprises must uphold the idea of continuous innovation, to ensure the survival and development of enterprises.

\section{Hypothesis development}

A healthy government-business relationship can reduce the financing constraints of enterprises, and lower financing constraints can help to enhance the eco-innovation of enterprises. The characteristics of innovation activities are distinct. For example, innovation activities are always long-term activities with high risk. Innovation requires enterprises to continuously invest funds for a long time. Innovation that merely depends on internal financing will encounter two major problems: First, the instability of internal financing leads to a fracture in the capital chain of innovation activities. Second, a sudden interruption or restart of innovation activities brings huge adjustment costs to an enterprise's innovation activities [29,30]. It is challenging to meet the capital demand of innovation with internal financing alone; as such, external financing is an indispensable 
source of capital for enterprise innovation [31]. Many studies found that financing constraints harm the R\&D and innovation capabilities of enterprises [31-34]. The external financing of enterprises can be divided into equity financing and debt financing. Good equity financing and debt financing can alleviate the financing constraints of enterprises, thus enhancing enterprise eco-innovation.

Furthermore, external investors have asymmetric information about enterprise innovation activities [35], and it is difficult for external investors to judge the enterprise's innovation capabilities and innovation prospects due to their information disadvantage. One of the manifestations of a healthy government-business relationship is that the relationship between government and enterprises is "clean." In this situation, the government's integrity and transparency are improved, and the enterprises' rent-seeking opportunities and behaviours are reduced. When the government is considering which businesses to support, such as in the form of government subsidies [36], tax exemptions [37], and government procurement [38], it strictly selects those businesses producing excellent innovations. By allocating public resources to innovative enterprises, the government transmits signals to the market to reduce the information asymmetry between enterprises and external investors, attract external funds, and reduce the financing constraints of enterprises.

China's financial system is a bank-led financial system, where the main financing method of enterprises is bank debt financing. Most banks are state-owned banks; therefore, they are greatly influenced by the government and policy guidance. Another manifestation of a healthy government-business relationship is cordiality. The government is concerned about enterprise development and provides high-quality infrastructure, financial services, and market intermediary services. A healthy relationship between government and business can help enterprises obtain bank loans and reduce financing constraints.

To sum up, a healthy government-business relationship means that the relationship between government and business is cordial and clean, which enables enterprises to obtain a good external financing environment and reduce financing constraints, thus helping to promote enterprise eco-innovation. Based on the above analysis, we proposed hypothesis 1.

Hypothesis 1: A healthy government-business relationship has a significant positive impact on enterprise eco-innovation.

Eco-innovation is a high-risk and long-term enterprise investment activity. A good external environment is necessary for enterprise eco-innovation, but enterprises are not necessarily willing to use the good business environment formed by healthy political business relationships to carry out eco-innovation. Principal-agent theory points out that the control rights and ownership of modern enterprises are separated and the principal-agent problem arises when maximising the private interests of managers. Enterprise innovation activities are conducive to the sustainable development of enterprises and enhancing their competitive advantages [20, 21, 39, 40]. Jensen and Meckling pointed out that when managerial ownership increases, the interests of the management and those of the shareholders tend to converge and the principal-agent cost decreases, forming an incentive compatibility effect [41]. Managerial ownership makes enterprises willing to engage with a good business environment for enterprise eco-innovation. Based on the above analysis, we believe that managerial ownership enhances the positive impact of a healthy government-business relationship on enterprise eco-innovation; hence, we proposed hypothesis 2 . 
Hypothesis 2: Managerial ownership significantly increases the positive impact of a healthy government-business relationship on enterprise eco-innovation.

From the perspective of institutional theory, governments in emerging economies play an important role in controlling and distributing scarce and key factor resources, such as capital, land, technology, and infrastructure [42]. As government-owned entities, SOEs have inherent advantages regarding obtaining government support, such as government subsidies and government procurement, forming a resource effect. Since SOEs are closely tied with the government, they have an inherent information effect that allows them to understand the government's policy guidelines and they face low policy uncertainty.

Since SOEs have won government support without an improvement in government-business relations, the effect of improvement of the government-business relationship on the SOEs may be limited. The relationship between non-SOEs and the government does not have as many advantages as that between SOEs and the government; therefore, with the improvement of the government-business relationship, the communication between non-SOEs and the government increases and their relationship improves. On the one hand, non-SOEs gradually obtain policy resources, such as government subsidies and bank loans, which were previously difficult to obtain, to reduce the resource constraints on eco-innovation in non-SOEs. On the other hand, non-SOEs have a greater understanding of policies and less information asymmetry, which can improve their expectations of the economic consequences of eco-innovation. Therefore, compared with the case of state-owned enterprises, a healthy government-business relationship has a stronger impact on the eco-innovation of non-SOEs. Based on the above analysis, we proposed hypothesis 3 .

Hypothesis 3: Compared with the case of SOEs, a healthy government-business relationship has a stronger positive impact on the eco-innovation of non-SOEs.

Based on the above three hypotheses, we constructed a theoretical model for this study, as shown in Figure 1.

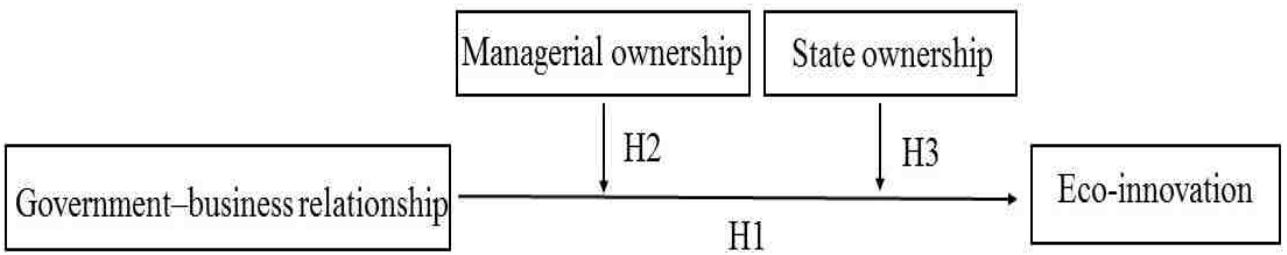

Fig. 1. Theoretical model

\section{Research design}

\section{Data and sample selection}

Our initial sample included all the automobile manufacturing companies listed in the Shanghai and Shenzhen A-share market from 2017 to 2019, and we divided the industries based on the 2012 industry classification standard issued by the China Securities Regulatory Commission. The government-business relationship was measured using the health index of China's urban government-business relationship issued by the National 
Academy of Development and Strategy (NADS), Renmin University of China. Other data were collected from the China Stock Market \& Accounting Research Database (CSMAR). The sample selection criteria were as follows: First, we deleted the listed companies with missing data. Second, we excluded companies with negative revenue, ST, and *ST. Our final sample included 334 firm-year observations.

\section{Variable definitions}

\section{Measurement of the government-business relationship}

The index of China's urban government-business relationship released by the NADS, Renmin University of China, has two dimensions: cordiality and cleanness [43]. The cordiality dimension includes three primary indicators: government care, government service, and corporate tax burden. The dimension of cleanness has two primary indicators: government integrity and government transparency. The index was first released in 2018 for the evaluation year of 2017, the second was released in 2019 for the evaluation year of 2018, and the third was released in 2020 for the evaluation year of 2019. Table 1 describes the composition of the indicators in the evaluation index system of China's urban government-business relationship.

Table 1

The evaluation index system of China's urban government-business relationship

\begin{tabular}{|c|c|c|}
\hline Dimensions & Primary indicators & Secondary indicators \\
\hline \multirow{3}{*}{ Cordiality } & $\begin{array}{c}\text { A: Government' s concern for } \\
\text { enterprises }(10 \%)\end{array}$ & $\begin{array}{l}\text { A1: Inspection times of government officials to } \\
\text { enterprises (5\%); A2: Number of discussions between } \\
\text { government officials and entrepreneurs (5\%) }\end{array}$ \\
\hline & $\begin{array}{c}\text { B: Government services to } \\
\text { enterprises }(40 \%)\end{array}$ & $\begin{array}{c}\text { B1: Infrastructure (10\%); B2: Financial service (10\%); } \\
\text { B3: Market intermediary (10\%); B4: E-government } \\
\text { efficiency }(10 \%)\end{array}$ \\
\hline & $\begin{array}{l}\text { C: Tax burden of enterprises } \\
(10 \%)\end{array}$ & $\mathrm{C} 1$ : Tax burden of enterprises $(10 \%)$ \\
\hline \multirow{2}{*}{ Cleanness } & $\begin{array}{l}\text { D: Government integrity } \\
(10 \%)\end{array}$ & $\begin{array}{l}\text { D1: Agency price of food safety license }(5 \%) \\
\text { D2: Baidu corruption index }(5 \%)\end{array}$ \\
\hline & $\begin{array}{c}\text { E: Government transparency } \\
(30 \%)\end{array}$ & $\begin{array}{l}\text { E1: Publicity of administrative information }(15 \%) \text {; } \\
\text { E2: Fiscal transparency }(15 \%)\end{array}$ \\
\hline
\end{tabular}

\section{Measurement of eco-innovation}

Following previous studies, such as Zhang et al. [44], Albino et al. [45], and Wu et al. [46], we used the number of green invention patent applications to measure enterprise eco-innovation. The China National Intellectual Property Administration (CNIPA) divides green patents into green invention patents and green utility models. Because green invention patents are the most innovative, in this study, we used the number of green invention patent applications to measure enterprise eco-innovation. In the later robustness test, we used the total number of green invention patent applications and green utility model applications to measure enterprise eco-innovation.

\section{Moderating variables}

Referring to Gotti et al. [47], and Shen and Hou [48], managerial ownership (MO) is equal to the number of shares held by the management divided by the total number of shares. Referring to prior research [46, 49] on state-owned enterprises (SOEs), we 
determined the nature of the enterprise according to the nature of the ultimate controller, with a value of 1 for SOEs and 0 for non-SOEs.

\section{Control variables}

Following prior studies [46, 48], we selected the following variables as control variables: leverage ratio $(L E V)$, corporate size $(S I Z E)$, sales revenue growth rate (SALGRO), return on total assets $(R O A)$, the shareholding ratio of the largest shareholder (TOP 1), the ratio of independent directors (IDRATIO), and board size (BODSIZE). The leverage ratio $(L E V)$ is the total liabilities divided by the total assets. Corporate size is the natural logarithm of the total assets. The sales revenue growth rate (SALGRO) is the sales of the financial year minus the sales of the previous year and then divided by the previous year's sales. The return on total assets $(R O A)$ is equal to the current net profit divided by the total assets. The shareholding ratio of the largest shareholder (TOP1) is equal to the number of shares held by the largest shareholder divided by the total share capital. The ratio of independent directors (IDRATIO) is equal to the number of independent directors divided by the total number of directors. Board size (BODSIZE) is the total number of directors on the board.

\section{Empirical model}

Hypothesis 1 predicted that a healthy government-business relationship is positively associated with enterprise eco-innovation. Model 1 was set to test hypothesis 1 . ZS is the independent variable that captured the government-business relationship. EI_INVEN was the dependent variable that was used to measure enterprise eco-innovation. Since there was a large number of zero values in the number of green invention patent applications, a zero-inflated Poisson regression was adopted here for the regression analysis. If the regression coefficient $\beta_{1}$ of $Z S$ is positive and significant, then hypothesis 1 is supported:

$$
\begin{gathered}
\text { EI_INVEN }=\beta_{0}+\beta_{1} Z S+\beta_{2} L E V+\beta_{3} S I Z E+\beta_{4} S A L G R O+\beta_{5} R O A+\beta_{6} T O P 1 \\
+\beta_{7} I D R A T I O+\beta_{8} B O D S I Z E+\varepsilon \text { Model } 1
\end{gathered}
$$

To test hypothesis 2, we employed the following model 2 by interacting $Z S$ with MO in model 1. EI_INVEN represents enterprise eco-innovation, and $Z S$ represents the government-business relationship. $M O$ stands for managerial ownership. If the coefficient $\beta_{2}$ of $Z S \cdot M O$ is positive and significant, then hypothesis 2 is supported.

$$
\begin{aligned}
\text { EI_INVEN }=\beta_{0} & +\beta_{1} Z S+\beta_{2} Z S \cdot M O+\beta_{3} M O+\beta_{4} L E V+\beta_{5} S I Z E+\beta_{6} S A L G R O \\
& +\beta_{7} R O A+\beta_{8} \text { TOP } 1+\beta_{9} I D R A T I O+\beta_{10} \text { BODSIZE }+\varepsilon \text { Model } 2
\end{aligned}
$$

To test hypothesis 3 , we added the interaction term $Z S \cdot S O E$ based on model 1 to form model 3. In model 3, EI_INVEN represents enterprise eco-innovation and SOE represents state ownership. If the coefficient $\beta_{2}$ of $Z S \cdot S O E$ is negative and significant, then hypothesis 3 is supported.

$$
\begin{aligned}
\text { EI_INVEN }=\beta_{0} & +\beta_{1} Z S+\beta_{2} Z S \cdot S O E+\beta_{3} S O E+\beta_{4} L E V+\beta_{5} S I Z E+\beta_{6} S A L G R O \\
& +\beta_{7} R O A+\beta_{8} T O P 1+\beta_{9} I D R A T I O+\beta_{10} B O D S I Z E+\varepsilon \text { Model } 3
\end{aligned}
$$




\section{Empirical results}

\section{Descriptive statistics}

Table 2 shows the descriptive statistics of our sample. The minimum, median, and $75 \%$ quantile values of EI_INVEN are zero, indicating that the vast majority of sample enterprises do not apply for green invention patents. Meanwhile, it also indicates that the zero-inflated Poisson model is suitable for adoption. The minimum value of $Z S$ is 7.88 , the median is 52.29 , and the maximum value is 100 , indicating a great difference in the health index of the government-business relationship between different cities. The median of $M O$ is 0.03 , which means that managerial ownership is relatively low in China's automobile manufacturing enterprises. The average SOE is 0.28 , indicating that $28 \%$ of enterprises in the automobile manufacturing industry belong to SOEs.

For the control variables, the average of $L E V$ is 0.44 , indicating that the leverage ratio of manufacturing enterprises is $44 \%$ on average. The average sample firm size (SIZE) is 22.51. The average sales revenue growth $(S A L G R O)$ is 1.44 , and the median is 0.06 , indicating that the sales revenue growth rate among automobile manufacturing enterprises is greatly different. The average $R O A$ is 0.03 , and the average of TOP 1 is 0.36 . The average of IDRATIO is 0.37 , indicating that $37 \%$ of the directors are independent. The minimum of $B O D S I Z E$ is 5, and the maximum of BODSIZE is 17, which complies with the provisions of China's Companies Act.

Table 2

Descriptive statistics

\begin{tabular}{|c|c|c|c|c|c|c|c|c|}
\hline Variable & $\boldsymbol{N}$ & Mean & $\boldsymbol{S D}$ & Min. & P25 & Median & P75 & Max. \\
\hline EI_INVEN & 334 & 2.32 & 13 & 0.00 & 0.00 & 0.00 & 0.00 & 194.00 \\
\hline ZS & 334 & 53.92 & 19 & 7.88 & 40.31 & 52.29 & 64.93 & 100.00 \\
\hline MO & 334 & 0.13 & 0.19 & 0.00 & 0.00 & 0.03 & 0.19 & 0.75 \\
\hline SOE & 334 & 0.28 & 0.45 & 0.00 & 0.00 & 0.00 & 1.00 & 1.00 \\
\hline LEV & 334 & 0.44 & 0.19 & 0.04 & 0.32 & 0.42 & 0.57 & 0.95 \\
\hline SIZE & 334 & 22.51 & 1.4 & 19.77 & 21.54 & 22.30 & 23.20 & 27.47 \\
\hline SALGRO & 334 & 1.44 & 23 & -0.56 & -0.05 & 0.06 & 0.20 & 429.04 \\
\hline ROA & 334 & 0.03 & 0.08 & -0.71 & 0.01 & 0.04 & 0.07 & 0.19 \\
\hline TOPI & 334 & 0.36 & 0.15 & 0.05 & 0.24 & 0.36 & 0.46 & 0.71 \\
\hline IDRATIO & 334 & 0.37 & 0.05 & 0.27 & 0.33 & 0.33 & 0.40 & 0.60 \\
\hline BODSIZE & 334 & 8.69 & 1.9 & 5.00 & 7.00 & 9.00 & 9.00 & 17.00 \\
\hline
\end{tabular}

\section{Pearson correlation analysis}

Table 3 presents the correlation coefficient matrix among the variables. The correlation coefficient between $Z S$ and EI_INVEN is significant at the $5 \%$ level, revealing that the government-business relationship is significantly positively correlated with enterprise eco-innovation and consistent with hypothesis 1 . In addition, EI_INVEN is significantly correlated with $L E V, S I Z E, I D R A T I O$, and BODSIZE, indicating that it is appropriate to select these variables to put into the empirical model. 
Pearson correlation analysis

\begin{tabular}{|c|c|c|c|c|c|c|c|c|c|c|c|}
\hline & \begin{tabular}{|c|}
$E I_{-}$ \\
$I N V E N$
\end{tabular} & $Z S$ & MO & SOE & $L E V$ & SIZE & $\begin{array}{l}\text { SAL } \\
\text { GRO }\end{array}$ & $\mathrm{ROA}$ & TOP1 & $\begin{array}{c}I D \\
\text { RATIO }\end{array}$ & $\begin{array}{l}\text { BOD } \\
\text { SIZEE }\end{array}$ \\
\hline EI_INVEN & 1.000 & & & & & & & & & & \\
\hline$Z S$ & $\begin{array}{l}0.138^{* *} \\
(0.011) \\
\end{array}$ & 1.000 & & & & & & & & & \\
\hline$M O$ & $\begin{array}{l}-0.027 \\
(0.618)\end{array}$ & $\begin{array}{c}0.046 \\
(0.404) \\
\end{array}$ & 1.000 & & & & & & & & \\
\hline$S O E$ & $\begin{array}{l}0.110^{* *} \\
(0.045)\end{array}$ & $\begin{array}{l}-0.004 \\
(0.949) \\
\end{array}$ & \begin{tabular}{|c|}
$-0.439^{* * *}$ \\
$(0.000)$
\end{tabular} & 1.000 & & & & & & & \\
\hline$L E V$ & $\mid \begin{array}{c}0.165^{* * *} \\
(0.002)\end{array}$ & $\begin{array}{l}-0.062 \\
(0.263)\end{array}$ & \begin{tabular}{|c|}
$-0.286^{* * *}$ \\
$(0.000)$
\end{tabular} & $\begin{array}{l}0.391^{* * * *} \\
(0.000)\end{array}$ & 1.000 & & & & & & \\
\hline SIZE & \begin{tabular}{|c|}
$0.352^{* * *}$ \\
$(0.000)$
\end{tabular} & $\begin{array}{c}0.058 \\
(0.293) \\
\end{array}$ & \begin{tabular}{|c|}
$-0.377^{* * * *}$ \\
$(0.000)$ \\
\end{tabular} & $\begin{array}{c}0.448^{* * * *} \\
(0.000) \\
\end{array}$ & $\begin{array}{c}0.549^{* * *} \\
(0.000) \\
\end{array}$ & 1.000 & & & & & \\
\hline SALGRO & \begin{tabular}{|l|}
-0.011 \\
$(0.846)$
\end{tabular} & $\begin{array}{c}0.010 \\
(0.857)\end{array}$ & \begin{tabular}{|l|}
-0.039 \\
$(0.477)$ \\
\end{tabular} & $\begin{array}{c}0.088 \\
(0.109) \\
\end{array}$ & $\begin{array}{c}0.055 \\
(0.320) \\
\end{array}$ & $\begin{array}{c}0.078 \\
(0.154) \\
\end{array}$ & 1.000 & & & & \\
\hline$R O A$ & \begin{tabular}{|c|}
0.006 \\
$(0.912)$
\end{tabular} & $\begin{array}{c}0.034 \\
(0.536)\end{array}$ & \begin{tabular}{c|}
0.056 \\
$(0.309)$ \\
\end{tabular} & $\begin{array}{l}-0.006 \\
(0.908)\end{array}$ & $\begin{array}{l}-0.298^{* * *} \\
(0.000)\end{array}$ & $\begin{array}{l}-0.033 \\
(0.545)\end{array}$ & $\begin{array}{l}-0.017 \\
(0.753)\end{array}$ & 1.000 & & & \\
\hline TOP1 & \begin{tabular}{|c|}
-0.019 \\
$(0.730)$ \\
\end{tabular} & $\begin{array}{c}0.072 \\
(0.193) \\
\end{array}$ & $\begin{array}{l}-0.063 \\
(0.249)\end{array}$ & $\begin{array}{c}0.021 \\
(0.700)\end{array}$ & $\begin{array}{c}0.013 \\
(0.819)\end{array}$ & $\begin{array}{l}0.097^{*} \\
(0.077)\end{array}$ & $\begin{array}{l}-0.041 \\
(0.459)\end{array}$ & $\begin{array}{c}0.084 \\
(0.127)\end{array}$ & 1.000 & & \\
\hline IDRATIO & $\begin{array}{c}0.192^{* * * *} \\
(0.000)\end{array}$ & $\begin{array}{l}0.142^{* * * *} \\
(0.009)\end{array}$ & $\begin{array}{c}0.005 \\
(0.932)\end{array}$ & $\begin{array}{l}-0.088 \\
(0.109)\end{array}$ & $\begin{array}{c}-0.123^{* *} \\
(0.025)\end{array}$ & $\begin{array}{l}-0.021 \\
(0.701)\end{array}$ & $\begin{array}{l}-0.006 \\
(0.919)\end{array}$ & $\begin{array}{c}0.010 \\
(0.857)\end{array}$ & $\begin{array}{l}-0.001 \\
(0.993)\end{array}$ & 1.000 & \\
\hline BODSIZE & $\begin{array}{l}0.123^{* *} \\
(0.024)\end{array}$ & $\begin{array}{l}-0.132^{* *} \\
(0.016)\end{array}$ & \begin{tabular}{|c|}
$-0.225^{* * *}$ \\
$(0.000)$
\end{tabular} & $\begin{array}{l}0.378^{* * * *} \\
(0.000)\end{array}$ & $\begin{array}{l}0.288^{* * * *} \\
(0.000)\end{array}$ & $\begin{array}{l}0.363^{* * *} \\
(0.000)\end{array}$ & $\begin{array}{c}0.065 \\
(0.235)\end{array}$ & $\begin{array}{l}-0.079 \\
(0.150)\end{array}$ & $\begin{array}{c}-0.134^{* *} \\
(0.014)\end{array}$ & $\begin{array}{l}-0.428^{* * *} \\
(0.000)\end{array}$ & 1.000 \\
\hline
\end{tabular}

1) $p$ values in parentheses; 2$){ }^{*} p<0.10,{ }^{* *} p<0.05,{ }^{* * *} p<0.01$

\section{Main analysis}

Columns (1), (2), and (3) of Table 4 respectively present the empirical test results of hypothesis 1 , hypothesis 2 , and hypothesis 3 . The coefficient of $Z S$ in column (1) is 0.019 , which is significant at the $1 \%$ level, indicating that the healthier the government-business relationship, the stronger the enterprise eco-innovation will be; hence, hypothesis 1 is supported. The coefficient of $Z S \cdot M O$ is significantly positive at the $1 \%$ level in column (2), suggesting that managerial ownership significantly improves the positive impact of the healthy government-business relationship on enterprise eco-innovation, so hypothesis 2 is supported. The $Z S \cdot S O E$ coefficient is -0.029 and is significantly positive at the $1 \%$ level in column (3), indicating that the healthy government-business relationship in non-SOEs has a stronger positive impact on enterprise eco-innovation, supporting hypothesis 3 .

Concerning other variables, the coefficient of $L E V$ is significantly positive, indicating that the higher the leverage ratio is, the more active the enterprise eco-innovation will be. The SIZE coefficient is significantly positive, indicating that the larger the corporate size, the more active the ecological innovation will be. SALGRO is significantly negative, indicating that sales revenue growth rate is negatively correlated with enterprise eco-innovation. The ROA coefficient is significantly positive, indicating that the return on total assets is positively correlated with enterprise eco-innovation. The TOPl coefficient is significantly negative, indicating that the shareholding ratio of the largest shareholder is negatively correlated with enterprise eco-innovation. IDRATIO and BODSIZE coefficients 
are significantly positive, indicating that the ratio of independent directors and board size are positively correlated with enterprise eco-innovation.

Regression results of the main analysis

\begin{tabular}{|c|c|c|c|}
\hline Variables & $\begin{array}{c}\text { (1) } \\
\text { EI_INVEN }\end{array}$ & $\begin{array}{c}(2) \\
\text { EI_INVEN }\end{array}$ & $\begin{array}{c}\text { (3) } \\
\text { EI_INVEN }\end{array}$ \\
\hline$Z S$ & $\begin{array}{c}0.019^{* * * *} \\
(7.62)\end{array}$ & $\begin{array}{c}0.012^{* * * *} \\
(4.08)\end{array}$ & $\begin{array}{c}0.034^{* * * *} \\
(8.38)\end{array}$ \\
\hline$Z S \cdot M O$ & & $\begin{array}{c}0.095^{\text {*** }} \\
(4.51)\end{array}$ & \\
\hline$M O$ & & $\begin{array}{c}-6.437^{* * * *} \\
(-3.81)\end{array}$ & \\
\hline$Z S \cdot S O E$ & & & $\begin{array}{c}-0.029^{* * * *} \\
(-5.36)\end{array}$ \\
\hline$S O E$ & & & 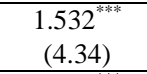 \\
\hline$L E V$ & $\begin{array}{l}4.875^{\text {**** }} \\
(10.08)\end{array}$ & $\begin{array}{c}3.952^{\text {**** }} \\
(7.76)\end{array}$ & $\begin{array}{c}3.727^{\text {*** }} \\
(7.26)\end{array}$ \\
\hline SIZE & $\begin{array}{l}0.140^{* * *} \\
(2.93)\end{array}$ & $\begin{array}{l}0.116^{* *} \\
(2.41)\end{array}$ & $\begin{array}{c}0.184^{* * * *} \\
(3.71)\end{array}$ \\
\hline$S A L G R O$ & $\begin{array}{c}-1.207^{* * *} \\
(-4.86)\end{array}$ & $\begin{array}{c}-0.962^{* * *} \\
(-3.77)\end{array}$ & $\begin{array}{c}-0.910^{* * * *} \\
(-3.67)\end{array}$ \\
\hline$R O A$ & $\begin{array}{l}18.03^{\text {***** }} \\
(10.16)\end{array}$ & $\begin{array}{c}16.88^{* * * *} \\
(9.56)\end{array}$ & $\begin{array}{c}14.53^{\text {**** }} \\
(8.26)\end{array}$ \\
\hline TOP1 & 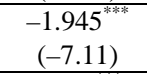 & $\begin{array}{c}-0.910^{\text {*** }} \\
(-2.57)\end{array}$ & $\begin{array}{l}-0.435 \\
(-1.17)\end{array}$ \\
\hline IDRATIO & $\begin{array}{l}7.280^{* * * *} \\
(10.50)\end{array}$ & $\begin{array}{c}5.666^{* * * *} \\
(7.26)\end{array}$ & $\begin{array}{c}5.079^{* * * *} \\
(6.69)\end{array}$ \\
\hline BODSIZE & 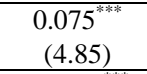 & $\begin{array}{c}0.108^{\text {*** }} \\
(5.95)\end{array}$ & $\begin{array}{c}0.124^{\text {**** }} \\
(6.97)\end{array}$ \\
\hline Constant & $\begin{array}{l}-8.403^{\text {*** }} \\
(-10.92)\end{array}$ & $\begin{array}{c}-6.946^{3 * \pi} \\
(-8.27)\end{array}$ & $\begin{array}{l}-9.761^{3 * *} \\
(-11.65)\end{array}$ \\
\hline Inflate_cons & $\begin{array}{c}1.266^{* * * *} \\
(8.32)\end{array}$ & $\begin{array}{c}1.279^{* * *} \\
(8.44)\end{array}$ & $\begin{array}{c}1.293^{* * *} \\
(8.53)\end{array}$ \\
\hline$N$ & 334 & 334 & 334 \\
\hline
\end{tabular}

1) $z$ statistics in parentheses; 2$) \stackrel{*}{p} p<0.10,{ }^{* *} p<0.05,{ }^{* * *} p<0.01$

\section{Robustness checks}

The following robustness tests were used to improve the robustness of the research conclusions: (1) changing the measurement method of independent variables; (2) changing the measurement method of the dependent variable; (3) using the fixed-effect model and random effect model; (4) adding control variables.

\section{Robustness check using alternative independent measurement}

Referring to Guan [50], the research samples are divided into 10 groups according to the score of government-business relationship from low to high, and assigned 1 to 10 in turn. For example, the score of $91-100$ is 10 , and the score of 1-10 is 1 . The new measurement method of government-business relationship is expressed as ZS2, and Table 5 shows the robustness test results after using alternative the variable measurement method. Column (1) reports the empirical results of the hypothesis 1 and suggests that the 
government-business relationship (ZS2) is positively and significantly associated with the measure of eco-innovation $(E I I I N V E N)$ at a $1 \%$ level $(0.162$ with $z=6.56)$, which indicates that the healthy government-business relationship promotes eco-innovation. As shown in column (2), the coefficient of $Z S 2 \cdot M O$ is significantly positive at $1 \%$ level ( 0.625 with $z=3.10)$, suggesting that managerial ownership enhances the strength of the association between the healthy government-business relationship and enterprise eco-innovation, validating hypothesis 2 . The coefficient for ZS2 $S O E$ in column (3) is negative at a $1 \%$ level $(-0.247$ with $z=-4.17)$, implying that the positive impact of the healthy government-business relationship on enterprise eco-innovation is stronger in non-SOEs. The empirical results in Table 5 show that hypothesis 1 , hypothesis 2 , and hypothesis 3 are still robust after using alternative independent measurement.

Table 5

Results of robustness check using alternative independent measurement

\begin{tabular}{|c|c|c|c|}
\hline Variables & $\begin{array}{c}(1) \\
\text { EI_INVEN }\end{array}$ & $\begin{array}{c}(2) \\
E I \_I N V E N \\
\end{array}$ & $\begin{array}{c}(3) \\
\text { EI_INVEN }\end{array}$ \\
\hline$Z S 2$ & $\begin{array}{c}0.162^{* * * *} \\
(6.56)\end{array}$ & $\begin{array}{c}0.115^{* * *} \\
(4.07)\end{array}$ & $\begin{array}{c}0.295^{* * * *} \\
(6.86)\end{array}$ \\
\hline $\mathrm{ZS} 2 \cdot \mathrm{MO}$ & & $\begin{array}{c}0.625^{* * *} \\
(3.10)\end{array}$ & \\
\hline$M O$ & & $\begin{array}{l}-4.513^{* * *} \\
(-2.55)\end{array}$ & \\
\hline$Z S 2 \cdot S O E$ & & & $\begin{array}{c}-0.247^{* * * *} \\
(-4.17)\end{array}$ \\
\hline$S O E$ & & & $\begin{array}{c}1.336^{* * *} \\
(3.18)\end{array}$ \\
\hline$L E V$ & $\begin{array}{c}4.878^{\text {***k }} \\
(9.95)\end{array}$ & $\begin{array}{c}4.349^{* * * *} \\
(8.64)\end{array}$ & $\begin{array}{c}3.885^{* * * 6} \\
(7.50)\end{array}$ \\
\hline$S I Z E$ & $\begin{array}{c}0.189^{* * *} \\
(4.10)\end{array}$ & $\begin{array}{c}0.187^{* * *} \\
(4.08)\end{array}$ & $\begin{array}{l}0.238^{* * *} \\
(5.02)\end{array}$ \\
\hline$S A L G R O$ & $\begin{array}{c}-1.111^{\text {**** }} \\
(-4.58)\end{array}$ & $\begin{array}{c}-1.051^{* * *} \\
(-4.23)\end{array}$ & $\begin{array}{c}-1.018^{* * *} \\
(-4.14) \\
\end{array}$ \\
\hline$R O A$ & $\begin{array}{c}17.86^{* * *} \\
(9.99)\end{array}$ & $\begin{array}{c}16.86^{* * *} \\
(9.39)\end{array}$ & $\begin{array}{c}14.31^{* * * *} \\
(7.92)\end{array}$ \\
\hline TOP1 & $\begin{array}{c}-2.225^{* * *} \\
(-8.34)\end{array}$ & $\begin{array}{c}-1.552^{* * *} \\
(-4.75)\end{array}$ & $\begin{array}{c}-0.749^{*} \\
(-1.87)\end{array}$ \\
\hline IDRATIO & $\begin{array}{l}7.399^{* * *} \\
(10.53)\end{array}$ & $\begin{array}{c}6.208^{* * *} \\
(7.90)\end{array}$ & $\begin{array}{c}5.304^{* * * *} \\
(6.67)\end{array}$ \\
\hline BODSIZE & $\begin{array}{c}0.068^{\text {**** }} \\
(4.18)\end{array}$ & $\begin{array}{c}0.090^{\text {**** }} \\
(4.94)\end{array}$ & $\begin{array}{c}0.113^{* * * *} \\
(6.11)\end{array}$ \\
\hline Constant & $\begin{array}{l}-9.471^{* * *} \\
(-12.70)\end{array}$ & $\begin{array}{l}-8.795^{* * *} \\
(-11.30)\end{array}$ & $\begin{array}{l}-10.87^{* * * *} \\
(-13.34)\end{array}$ \\
\hline Inflate_cons & $\begin{array}{c}1.237^{\text {**** }} \\
(8.06)\end{array}$ & $\begin{array}{c}1.237^{* * * *} \\
(8.05)\end{array}$ & $\begin{array}{c}1.275^{* * *} \\
(8.37)\end{array}$ \\
\hline$N$ & 334 & 334 & 334 \\
\hline
\end{tabular}

1) $z$ statistics in parentheses; 2$){ }^{*} p<0.10,{ }^{* *} p<0.05,{ }^{* * *} p<0.01$

\section{Robustness check using alternative dependent measurement}

Referring to the research method of Shen and Hou [48], we sum up the number of green invention patents and green utility model patents to construct a new variable EI_Total, which is used to measure the enterprise eco-innovation. Table 6 shows the 
robustness test results after changing the eco-innovation measurement method. The coefficient of $Z S$ in column (1) is significantly positive at a $1 \%$ level $(0.019$ with $z=11.26$ ), revealing that a healthy government-business relationship enhances enterprise eco-innovation. As shown in column (2), the coefficient estimate for $Z S \cdot M O$ is significantly positive $(0.081$ with $z=5.68)$, indicating that managerial ownership enhances the positive impact of a healthy government-business relationship on enterprise eco-innovation. The coefficient of $Z S \cdot S O E$ in column (3) is -0.014 , which is significant at the $1 \%$ level, indicating that the positive impact of a healthy government-business relationship on enterprise eco-innovation is stronger in non-SOEs. The empirical results in Table 6 show that hypothesis 1, hypothesis 2, and hypothesis 3 are still robust after changing the measurement method of enterprise eco-innovation.

Table 6

Results of robustness check using alternative dependent measurement

\begin{tabular}{|c|c|c|c|}
\hline Variables & $\begin{array}{c}(1) \\
\text { EI_TOTAL }\end{array}$ & $\begin{array}{c}(2) \\
\text { EI_TOTAL }\end{array}$ & $\begin{array}{c}(3) \\
\text { EI_TOTAL }\end{array}$ \\
\hline$Z S$ & $\begin{array}{l}0.019^{* * *} \\
(11.26)\end{array}$ & $\begin{array}{c}0.013^{* * *} \\
(6.37)\end{array}$ & $\begin{array}{c}0.025^{* * *} \\
(9.12)\end{array}$ \\
\hline$Z S \cdot M O$ & & $\begin{array}{c}0.081^{* * * *} \\
(5.68)\end{array}$ & \\
\hline$M O$ & & $\begin{array}{c}-4.421^{\text {****k }} \\
(-4.09)\end{array}$ & \\
\hline$Z S \cdot S O E$ & & & $\begin{array}{c}-0.014^{* * *} \\
(-3.65)\end{array}$ \\
\hline$S O E$ & & & $\begin{array}{l}0.320 \\
(1.30)\end{array}$ \\
\hline$L E V$ & $\begin{array}{l}5.137^{\text {***** }} \\
(14.27)\end{array}$ & $\begin{array}{l}4.133^{\text {**** }} \\
(10.73)\end{array}$ & $\begin{array}{l}4.186^{* * * 6} \\
(10.55)\end{array}$ \\
\hline SIZE & $\begin{array}{c}0.128^{* * * *} \\
(3.65)\end{array}$ & $\begin{array}{c}0.118^{* * *} \\
(3.29)\end{array}$ & $\begin{array}{c}0.224^{* * *} \\
(5.83)\end{array}$ \\
\hline SALGRO & $\begin{array}{c}-0.917^{\text {**** }} \\
(-5.42)\end{array}$ & $\begin{array}{c}-0.822^{* * * *} \\
(-4.79)\end{array}$ & $\begin{array}{c}-0.801^{\text {*** }} \\
(-4.83)\end{array}$ \\
\hline$R O A$ & $\begin{array}{l}18.14^{\text {**** }} \\
(13.34)\end{array}$ & $\begin{array}{l}17.30^{* * * *} \\
(12.73)\end{array}$ & $\begin{array}{l}15.56^{\text {**** }} \\
(11.35)\end{array}$ \\
\hline TOP1 & $\begin{array}{l}-2.229^{* * *} \\
(-10.79)\end{array}$ & $\begin{array}{c}-1.059^{* * * *} \\
(-4.01)\end{array}$ & $\begin{array}{c}-1.366^{* * *} \\
(-4.90)\end{array}$ \\
\hline IDRATIO & $\begin{array}{l}6.344^{* * *} \\
(11.70)\end{array}$ & $\begin{array}{c}4.301^{* * *} \\
(6.91)\end{array}$ & $\begin{array}{c}4.703^{* * *} \\
(7.81)\end{array}$ \\
\hline BODSIZE & $\begin{array}{c}0.069^{\text {* }} \\
(5.96)\end{array}$ & $\begin{array}{c}0.119^{\text {*3* }} \\
(8.67)\end{array}$ & $\begin{array}{c}0.115^{\text {**ak }} \\
(8.88)\end{array}$ \\
\hline Constant & $\begin{array}{l}-7.286^{* * *} \\
(-13.38)\end{array}$ & $\begin{array}{c}-6.265^{\text {*** }} \\
(-10.29)\end{array}$ & $\begin{array}{l}-9.161^{\text {*** }} \\
(-14.65)\end{array}$ \\
\hline Inflate_cons & $\begin{array}{c}1.216^{* * *} \\
(8.67)\end{array}$ & $\begin{array}{c}1.233^{\text {**** }} \\
(8.82)\end{array}$ & $\begin{array}{c}1.240^{* * *} \\
(8.88)\end{array}$ \\
\hline$N$ & 334 & 334 & 334 \\
\hline
\end{tabular}

1) $z$ statistics in parentheses; 2$)^{*} p<0.10,{ }^{* * *} p<0.05,{ }^{* * *} p<0.01$

Robustness check using random effect panel Poisson regression and fixed effect panel Poisson regression

The random effect panel Poisson regression and fixed effect panel Poisson regression are used for the robustness test. The results of the robustness test are reported in Table 7. 
Columns (1) - (3) are the results of random effect panel Poisson regression analysis, and the coefficient of $Z S$ in column (1) is positive and significant $(0.022$ with $z=4.37)$, indicating that the healthy government-business relationship promotes enterprise eco-innovation. The coefficient of $Z S \cdot M O$ in column (2) is positive and significant at the $1 \%$ level ( 0.274 with $z=5.62)$, indicating that managerial ownership enhances the positive impact of a healthy government-business relationship on enterprise eco-innovation. The coefficient of $Z S \cdot S O E$ in column (3) is negative and significant at the $1 \%$ level $(-0.111$ with $z=-8.50)$, indicating that the positive impact of a healthy government-business relationship on enterprise eco-innovation is stronger in non-SOEs. The empirical results presented in columns (1)-(3) of Table 7 show that hypothesis 1, hypothesis 2, and hypothesis 3 are still robust by using random effect panel Poisson regression.

Results of robustness check using random effect panel Poisson regression

Table 7 and fixed effect panel Poisson regression

\begin{tabular}{|c|c|c|c|c|c|c|}
\hline \multirow[b]{2}{*}{ Variables } & \multicolumn{3}{|c|}{ Random effect panel Poisson regression } & \multicolumn{3}{|c|}{ Fixed effect panel Poisson regression } \\
\hline & $\begin{array}{c}\text { (1) } \\
\text { EI_INVEN }\end{array}$ & $\begin{array}{c}(2) \\
\text { EI_INVEN }\end{array}$ & $\begin{array}{c}\text { (3) } \\
\text { EI_INVEN }\end{array}$ & $\begin{array}{c}\text { (4) } \\
\text { EI_INVEN }\end{array}$ & $\begin{array}{c}\text { (5) } \\
\text { EI_INVEN }\end{array}$ & $\begin{array}{c}(6) \\
E I \_I N V E N\end{array}$ \\
\hline$Z S$ & $\begin{array}{c}0.022^{* * *} \\
(4.37)\end{array}$ & $\begin{array}{c}0.012^{* * *} \\
(2.38)\end{array}$ & $\begin{array}{c}0.099^{* * *} \\
(8.40)\end{array}$ & $\begin{array}{l}0.0001 \\
(0.02) \\
\end{array}$ & $\begin{array}{l}-0.006 \\
(-1.01) \\
\end{array}$ & $\begin{array}{c}0.076^{* * *} \\
(4.64)\end{array}$ \\
\hline$Z S \cdot M O$ & & $\begin{array}{c}0.274^{* * * *} \\
(5.62)\end{array}$ & & & $\begin{array}{c}0.285^{* * * *} \\
(3.21)\end{array}$ & \\
\hline$M O$ & & $\begin{array}{c}-19.16^{\text {*⿻一未 }} \\
(-4.58)\end{array}$ & & & $\begin{array}{l}7.951 \\
(0.40) \\
\end{array}$ & \\
\hline$Z S \cdot S O E$ & & & $\begin{array}{c}-0.111^{* * * *} \\
(-8.50)\end{array}$ & & & $\begin{array}{c}-0.102^{* * * *} \\
(-5.37)\end{array}$ \\
\hline$S O E$ & & & $\begin{array}{l}12.36^{* * * k} \\
(11.03)\end{array}$ & & & $\begin{array}{l}12.13^{* * * *} \\
(10.04)\end{array}$ \\
\hline$L E V$ & $\begin{array}{c}6.283^{* *} \\
(2.82)\end{array}$ & $\begin{array}{c}8.487^{* * * *} \\
(4.84)\end{array}$ & $\begin{array}{l}0.608 \\
(0.29)\end{array}$ & $\begin{array}{c}29.72^{\text {**ak }} \\
(6.25)\end{array}$ & $\begin{array}{c}31.47^{* * *} \\
(6.56)\end{array}$ & $\begin{array}{l}10.85^{*} \\
(1.82) \\
\end{array}$ \\
\hline$S I Z E$ & $\begin{array}{l}-0.912 \\
(-1.34)\end{array}$ & $\begin{array}{c}-1.524^{* * * *} \\
(-9.45)\end{array}$ & $\begin{array}{l}-2.417^{* * *} \\
(-12.53)\end{array}$ & $\begin{array}{l}-16.76^{* * * *} \\
(-13.43)\end{array}$ & $\begin{array}{c}-16.17^{* * *} \\
(-12.79)\end{array}$ & $\begin{array}{l}-13.85^{* * * *} \\
(-10.89)\end{array}$ \\
\hline SALGRO & $\begin{array}{c}-0.665^{* *} \\
(-2.04)\end{array}$ & $\begin{array}{l}-0.157 \\
(-0.52)\end{array}$ & $\begin{array}{l}0.014 \\
(0.60)\end{array}$ & $\begin{array}{c}-1.115^{\text {**** }} \\
(-3.21)\end{array}$ & $\begin{array}{l}-0.625^{*} \\
(-1.67)\end{array}$ & $\begin{array}{l}0.223 \\
(0.53)\end{array}$ \\
\hline$R O A$ & $\begin{array}{c}24.43^{\text {***** }} \\
(7.57)\end{array}$ & $\begin{array}{c}27.32^{* * * *} \\
(9.36)\end{array}$ & $\begin{array}{c}21.05^{\text {*3*k }} \\
(7.64)\end{array}$ & $\begin{array}{c}36.43^{\text {*)* }} \\
(9.27)\end{array}$ & $\begin{array}{c}37.39^{* * * *} \\
(9.41)\end{array}$ & $\begin{array}{c}26.22^{* * * *} \\
(6.10)\end{array}$ \\
\hline TOP1 & $\begin{array}{l}3.754^{* * *} \\
(2.06)\end{array}$ & $\begin{array}{l}1.660 \\
(1.17) \\
\end{array}$ & $\begin{array}{l}3.500^{* * *} \\
(2.36)\end{array}$ & $\begin{array}{l}2.516 \\
(0.95) \\
\end{array}$ & $\begin{array}{l}0.366 \\
(0.14) \\
\end{array}$ & $\begin{array}{l}5.202^{*} \\
(1.91) \\
\end{array}$ \\
\hline IDRATIO & $\begin{array}{c}15.20^{* * * * 4} \\
(6.59)\end{array}$ & $\begin{array}{c}12.31^{\text {**** }} \\
(6.01)\end{array}$ & $\begin{array}{c}9.727^{\text {**⿲丶丶㇒木 }} \\
(4.56)\end{array}$ & $\begin{array}{l}-0.698 \\
(-0.23)\end{array}$ & $\begin{array}{l}-2.519 \\
(-0.83)\end{array}$ & $\begin{array}{l}-1.150 \\
(-0.40)\end{array}$ \\
\hline BODSIZE & 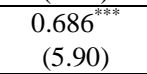 & $\begin{array}{c}0.663^{\text {***** }} \\
(7.70)\end{array}$ & $\begin{array}{c}0.545^{\text {*6*k }} \\
(5.73)\end{array}$ & $\begin{array}{c}0.951^{\text {*3* }} \\
(7.95)\end{array}$ & $\begin{array}{c}0.905^{\text {*3* }} \\
(7.90)\end{array}$ & $\begin{array}{c}0.829^{* * * k} \\
(7.24)\end{array}$ \\
\hline Constant & $\begin{array}{l}-1.595 \\
(-0.11)\end{array}$ & $\begin{array}{c}13.08^{* * *} \\
(3.92)\end{array}$ & $\begin{array}{c}27.28^{* * *} \\
(6.51)\end{array}$ & & & \\
\hline$N$ & 334 & 334 & 334 & 95 & 95 & 95 \\
\hline
\end{tabular}

1) $z$ statistics in parentheses; 2$){ }^{*} p<0.10,{ }^{* *} p<0.05,{ }^{* * *} p<0.01$

Columns (4)-(6) are the results of fixed effect Poisson regression analysis. The coefficient of $Z S$ in column (4) is 0.0001 , which is positive but not significant. The coefficient of $Z S \cdot M O$ in column (5) is positive and significant at the $1 \%$ level ( 0.285 with $z=3.21)$, indicating that managerial ownership significantly enhances the positive impact of the healthy government-business relationship on enterprise 
eco-innovation. The coefficient of $Z S \cdot S O E$ in column (6) is negative and significant at the $1 \%$ level, indicating that the positive impact of a healthy government-business relationship on enterprise eco-innovation is stronger in non-SOEs. The empirical results presented in columns (4)-(6) of Table 7 show that hypothesis 2 and hypothesis 3 are still robust with fixed effect panel Poisson regression.

\section{Robustness check using additional control variables}

To control the omitted variable bias, we add $R D, A G E$, and $D U A L$ into control variables. $R D$ is the natural logarithm of $\mathrm{R} \& \mathrm{D}$ expenses. $A G E$, the difference between the minus the year of establishment of the enterprise is calculated by natural logarithm. If the chairman and CEO are concurrently appointed by the same person, the value of DUAL is 1 ; otherwise, the value is 0 .

Table 8 shows the results of the robustness test after using additional control variables. The coefficient of $Z S$ in column (1) is positive and significant at the $1 \%$ level (0.015 with $z=5.50)$, indicating that the healthy government-business relationship promotes enterprise eco-innovation. The coefficient of $Z S \cdot M O$ in column (2) is positive and significant at $1 \%$ ( 0.132 with $z=5.62)$, indicating that managerial ownership enhances the positive impact of a healthy government-business relationship on the enterprise eco-innovation. The coefficient of ZS $\cdot S O E$ in column (3) is negative and significant at the $1 \%$ level $(-0.037$ with $z=-5.33)$, indicating that a healthy government-business relationship has a stronger positive impact on enterprise eco-innovation. The empirical results shown in Table 8 show that hypothesis 1, hypothesis 2, and hypothesis 3 are still robust after increasing control variables.

Results of robustness check using additional control variables

Table 8

\begin{tabular}{|c|c|c|c|}
\hline Variables & $\begin{array}{c}(1) \\
E I \_I N V E N\end{array}$ & $\begin{array}{c}(2) \\
E I \_I N V E N\end{array}$ & $\begin{array}{c}\text { (3) } \\
\text { EI_INVEN }\end{array}$ \\
\hline$Z S$ & $\begin{array}{c}0.015^{* * * *} \\
(5.50)\end{array}$ & $\begin{array}{l}-0.002 \\
(-0.51)\end{array}$ & $\begin{array}{c}0.031^{* * *} \\
(6.69)\end{array}$ \\
\hline$Z S \cdot M O$ & & $\begin{array}{c}0.132^{* * *} \\
(5.62)\end{array}$ & \\
\hline$M O$ & & $\begin{array}{l}-4.954^{* * \pi / 4} \\
(-2.77)\end{array}$ & \\
\hline$Z S \cdot S O E$ & & & $\begin{array}{c}-0.037^{* * *} \\
(-5.33)\end{array}$ \\
\hline$S O E$ & & & $\begin{array}{c}1.750^{* * * * 6} \\
(4.17)\end{array}$ \\
\hline$L E V$ & $\begin{array}{c}5.201^{* * * *} \\
(9.64)\end{array}$ & $\begin{array}{c}4.748^{* * * *} \\
(8.59)\end{array}$ & $\begin{array}{c}4.085^{* * m+} \\
(7.24)\end{array}$ \\
\hline SIZE & $\begin{array}{c}0.340^{* * * *} \\
(2.62)\end{array}$ & $\begin{array}{c}0.370^{* * * *} \\
(2.83)\end{array}$ & $\begin{array}{c}0.724^{* * * *} \\
(5.03)\end{array}$ \\
\hline$S A L G R O$ & $\begin{array}{c}-1.363^{* * *+1} \\
(-5.22)\end{array}$ & $\begin{array}{c}-0.735^{* * * 6} \\
(-2.80)\end{array}$ & $\begin{array}{c}-0.694^{* * * * \pi} \\
(-2.60)\end{array}$ \\
\hline$R O A$ & $\begin{array}{l}19.32^{* * * *} \\
(10.06)\end{array}$ & $\begin{array}{c}20.74^{* * * *} \\
(10.64)\end{array}$ & $\begin{array}{c}14.17^{* * *} \\
(7.33)\end{array}$ \\
\hline TOP1 & $\begin{array}{r}-3.102^{* *+4} \\
(-6.82)\end{array}$ & $\begin{array}{l}-2.672^{* * *} \\
(-5.41)\end{array}$ & $\begin{array}{c}-2.518^{* * * *} \\
(-4.77)\end{array}$ \\
\hline IDRATIO & $\begin{array}{c}6.941^{\text {**** }} \\
(9.79)\end{array}$ & $\begin{array}{l}2.035^{* *} \\
(2.15)\end{array}$ & $\begin{array}{c}3.098^{* * * *} \\
(3.36)\end{array}$ \\
\hline
\end{tabular}




\begin{tabular}{|c|c|c|c|}
\hline Variables & $\begin{array}{c}(1) \\
E I \_I N V E N\end{array}$ & $\begin{array}{c}(2) \\
E I \_I N V E N\end{array}$ & $\begin{array}{c}(3) \\
E I \_I N V E N\end{array}$ \\
\hline BODSIZE & $\begin{array}{c}0.047^{* *} \\
(2.46)\end{array}$ & $\begin{array}{c}0.117^{* * *} \\
(5.37)\end{array}$ & $\begin{array}{c}0.071^{* * *} \\
(3.59)\end{array}$ \\
\hline$R D$ & $\begin{array}{l}-0.070 \\
(-0.71)\end{array}$ & $\begin{array}{l}0.112 \\
(1.12)\end{array}$ & $\begin{array}{c}-0.240^{\text {*** }} \\
(-2.42)\end{array}$ \\
\hline$A G E$ & $\begin{array}{c}-1.553^{\text {**ak }} \\
(-5.23)\end{array}$ & $\begin{array}{c}-1.829^{\text {**** }} \\
(-5.81)\end{array}$ & $\begin{array}{c}-0.941^{\text {*** }} \\
(-2.99)\end{array}$ \\
\hline$D U A L$ & $\begin{array}{c}-0.708^{* * *} \\
(-3.93)\end{array}$ & $\begin{array}{c}-2.011^{\text {**** }} \\
(-7.14)\end{array}$ & $\begin{array}{c}-1.175^{* * *} \\
(-5.48)\end{array}$ \\
\hline Constant & $\begin{array}{c}-6.265^{* * * *} \\
(-6.62)\end{array}$ & $\begin{array}{c}-7.748^{\text {**** }} \\
(-7.32)\end{array}$ & $\begin{array}{c}-12.82^{* * * *} \\
(-8.67)\end{array}$ \\
\hline Inflate_cons & $\begin{array}{c}1.178^{* * * *} \\
(7.44)\end{array}$ & $\begin{array}{c}1.061^{\text {**** }} \\
(6.59)\end{array}$ & $\begin{array}{c}1.114^{\text {*** }} \\
(6.74)\end{array}$ \\
\hline$N$ & 334 & 334 & 334 \\
\hline
\end{tabular}

1) $z$ statistics in parentheses; 2$) \stackrel{*}{p} p<0.10,{ }^{* *} p<0.05,{ }^{* * * *} p<0.01$

\section{Mediation mechanism test}

In this part, we empirically tested whether a healthy government-business relationship can affect enterprise eco-innovation through financing constraints. Referring to the research of Hadlock and Pierce [51] and Wen et al. [52], this paper uses the SA index to measure corporate financing constraints. The calculation formula is: $S A=-0.737 \cdot S I Z E+$ $0.043 \cdot S I Z E^{2}-0.04 \cdot A G E$. In this formula, SIZE is the natural logarithm of the total assets of the enterprise, $A G E$ is the establishment period of the enterprise. Both SA index and control variables use the variable of corporate size. To alleviate the endogenous problem, we use the natural logarithm of total market value to measure corporate size.

We used Baron and Kenny's causal steps approach method to test the mediating effect of financing constraints [53]. The first step is to test the total effect of the independent variable (government-business relationship) on the dependent variable (eco-innovation) by using the previous Model 1. In the second step, we used Model 4 to test the influence of independent variables (government-business relationship) on mediating variables (financing constraints). In the third step, we added mediating variables (financing constraints) as independent variables on the basis of the first step, and used Model 5 to test the impact of mediating variables (financing constraints) on dependent variables (eco-innovation). Wen and Ye [54] and Gao and Han [55] summarise the above logic through Figure 2. As shown in Figure 2, if the coefficients $c$ and $a$ are significant, and the coefficient $b$ of financing constraints in the third step is also significant, then there is a mediating effect. On this basis, if the coefficient $c^{\prime}$ is not significant, it means that it is a complete mediating effect; and if the coefficient $c^{\prime}$ is significant, it means that it is a partial mediating effect.

$$
\begin{aligned}
& E I_{-} I N V E N=\beta_{0}+\beta_{1} Z S+\beta_{2} L E V+\beta_{3} S I Z E+\beta_{4} S A L G R O+\beta_{5} R O A+\beta_{6} T O P 1 \\
& +\beta_{7} \text { IDRATIO }+\beta_{8} \text { BODSIZE }+\varepsilon \text { Model } 1 \\
& S A=\beta_{0}+\beta_{1} Z S+\beta_{2} L E V+\beta_{3} S I Z E+\beta_{4} S A L G R O+\beta_{5} R O A+\beta_{6} T O P 1+\beta_{7} I D R A T I O \\
& +\beta_{8} B O D S I Z E+\varepsilon \text { Model } 4 \\
& \text { EI_INVEN }=\beta_{0}+\beta_{1} Z S+\beta_{2} S A+\beta_{3} L E V+\beta_{4} S I Z E+\beta_{5} S A L G R O+\beta_{6} R O A+\beta_{7} T O P 1 \\
& +\beta_{8} I D R A T I O+\beta_{9} \text { BODSIZE }+\varepsilon \text { Model } 5
\end{aligned}
$$




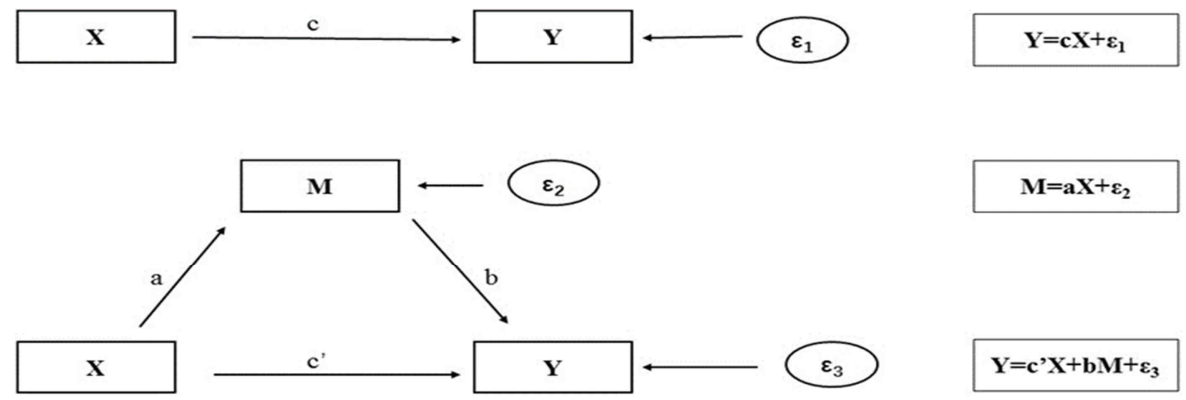

Fig. 2. Causal steps approach

Results of causal steps approach

Table 9

\begin{tabular}{|c|c|c|c|}
\hline Variables & $\begin{array}{c}\text { (1) } \\
\text { EI_INVEN }\end{array}$ & $\begin{array}{l}(2) \\
S A\end{array}$ & $\begin{array}{c}\text { (3) } \\
\text { EI_INVEN }\end{array}$ \\
\hline$Z S$ & $\begin{array}{c}0.019^{* * * *} \\
(7.62)\end{array}$ & $\begin{array}{c}0.001^{* * *} \\
(3.92)\end{array}$ & $\begin{array}{c}0.015^{* * *} \\
(6.36)\end{array}$ \\
\hline$S A$ & & & $\begin{array}{c}-4.217^{\text {*** }} \\
(-8.27)\end{array}$ \\
\hline$L E V$ & $\begin{array}{l}4.875^{* * * *} \\
(10.08)\end{array}$ & $\begin{array}{c}-0.091^{\text {*** }} \\
(-2.60)\end{array}$ & $\begin{array}{c}4.502^{\text {***k }} \\
(9.09)\end{array}$ \\
\hline SIZE & $\begin{array}{c}0.140^{* * * *} \\
(2.93)\end{array}$ & $\begin{array}{l}1.251^{* * * *} \\
(106.25)\end{array}$ & $\begin{array}{c}6.069^{* * * *} \\
(8.44)\end{array}$ \\
\hline SALGRO & $\begin{array}{c}-1.207^{\text {***** }} \\
(-4.86)\end{array}$ & $\begin{array}{c}-0.00003 \\
(-0.76)\end{array}$ & $\begin{array}{c}-0.899^{\text {*** }} \\
(-3.71)\end{array}$ \\
\hline$R O A$ & $\begin{array}{l}18.03^{* * *} \\
(10.16)\end{array}$ & $\begin{array}{l}0.012 \\
(0.23)\end{array}$ & $\begin{array}{c}15.56^{* * * *} \\
(9.21)\end{array}$ \\
\hline TOP1 & $\begin{array}{c}-1.945^{\text {*** }} \\
(-7.11)\end{array}$ & $\begin{array}{l}0.094^{* * *} \\
(2.00)\end{array}$ & $\begin{array}{c}-0.910^{\text {***** }} \\
(-2.95)\end{array}$ \\
\hline IDRATIO & $\begin{array}{l}7.280^{* * * *} \\
(10.50)\end{array}$ & $\begin{array}{c}0.787^{\text {**ak }} \\
(6.31)\end{array}$ & $\begin{array}{c}5.831^{\text {*3/2* }} \\
(8.46)\end{array}$ \\
\hline BODSIZE & $\begin{array}{c}0.075^{* * *} \\
(4.85)\end{array}$ & $\begin{array}{l}0.007 \\
(1.38)\end{array}$ & $\begin{array}{l}0.015 \\
(0.94)\end{array}$ \\
\hline Constant & $\begin{array}{l}-8.403^{\text {*** }} \\
(-10.92)\end{array}$ & $\begin{array}{l}-23.41^{\text {***ak }} \\
(-92.40)\end{array}$ & $\begin{array}{c}-119.8^{* * * * *} \\
(-8.82)\end{array}$ \\
\hline Inflate_cons & $\begin{array}{c}1.266^{* * * *} \\
(8.32)\end{array}$ & & $\begin{array}{c}0.921^{\text {**** }} \\
(5.40)\end{array}$ \\
\hline$N$ & 334 & 334 & 334 \\
\hline
\end{tabular}

1) $z / t$ statistics in parentheses; 2$){ }^{*} p<0.10,{ }^{* *} p<0.05,{ }^{* * *} p<0.01$

Table 9 shows the regression results of the causal steps approach. The coefficient of $Z S$ in column (1) is significantly positive at the $1 \%$ level $(0.019$ with $z=7.62)$, then the first step is established. The $Z S$ coefficient in column (2) is significantly positive at the $1 \%$ level (0.001 with $t=3.92)$, and the second step is established. The coefficients of $Z S$ and $S A$ in column (3) are significant at the same time, indicating that financial constraints play a partial mediating effect on the impact of the government-business relationship on eco-innovation. 


\section{Conclusion}

In China, Japan, South Korea, and other countries where the government plays a strong role in the economy and market, the impact of the government-business relationship on microenterprise behaviour needs to be paid attention to. In this study, we used 2017-2019 Chinese A-share-listed automobile manufacturing companies as research samples to analyse the impact of the government-business relationship on eco-innovation and its mechanism in the Chinese context. We found that a healthy government-business relationship had a positive impact on enterprise eco-innovation. The mediating mechanism test confirmed that a healthy government-business relationship affected enterprise eco-innovation through financing constraints. In addition, the positive impact of managerial ownership enhanced the effect of a healthy government-business relationship on enterprise eco-innovation. Considering state ownership, in non-SOEs, a healthy government-business relationship had a stronger positive impact on enterprise eco-innovation. After a series of robustness tests, such as using alternative independent variables, using alternative dependent variables, and changing regression methods, the conclusion was still valid. Our research enhanced the understanding of the impact of the business environment on the micro behaviour of enterprises and found new factors that influenced enterprise eco-innovation.

Based on the above conclusions, we propose the following research implications. Regarding theoretical implications, this study incorporates the government-business relationship into the analytical framework of enterprise eco-innovation. We also explore the roles of managerial ownership and state ownership mechanism in enterprise eco-innovation. These variables provide a new perspective for the study of enterprise eco-innovation. In addition, our research complements previous studies by empirically examining the mediating role of financing constraints, and it helps bridge the boundary between government-business relationship and enterprise eco-innovation. Our research setting enables us to provide a platform for continued discussion from this perspective.

Regarding policy implications, our study verifies the impact of the government-business relationship on enterprise eco-innovation, and it can be inferred that the government-business relationship has an impact on the decision-making and behaviour of enterprises. In "strong government" countries, such as China, Japan, and South Korea, the government has more power and can provide enterprises with more resources. Therefore, the governments of these countries need to restrain their behaviour, attach importance to the construction of the relationship between government and enterprises, and consider the influence of their behaviour on the decision-making and behaviour of microenterprises. Previous studies have shown that manager policies influence executive behaviour [56]. On the one hand, this requires government to pay attention to the relationship with enterprises by providing policy support such as appropriate property rights protection system and effective contract enforcement mechanism. On the other hand, the government should also pay attention to establishing a reasonable and fair relationship between government and business by setting restrictions on the abuse of government power and weakening the opportunity for rent-seeking.

Regarding management implications, the government-business relationship is an important aspect of the business environment. As they are located in countries that are deeply influenced by East Asian cultural traditions, companies in China, Japan, and South Korea should pay more attention to the meaning of "guan xi" in their business activities. 
Enterprises in countries like China, Japan, and South Korea should learn to manage their relationships with their respective governments, strive to obtain support from the government, and make appropriate responses in their decision-making according to the relationship between enterprises and the government. In addition, our research finds that property rights and corporate governance mechanisms play important roles in the influence of the government-business relationship on enterprise eco-innovation. Therefore, enterprises should correctly identify, understand and incorporate the roles of property rights and corporate governance mechanisms into their business practices. In the practice of enterprise management, managers should consider the influences of macro-political and policy factors on enterprise performance to better adapt to the external environment, make reasonable countermeasures, and improve the ability of enterprises to resist risks and manage performance.

In the context of China, the government plays an important role in resource allocation, while Western governments play a "night watchman" role, which has a relatively small impact on the economy and market. As such, in the Western context, is the influence of the government-business relationship on enterprise eco-innovation still present? If so, is the mechanism of action different? In addition, we speculate that Japan, South Korea, and other East Asian countries with similar history and culture to China have the same government-business relationship and eco-innovation [57], but we also need follow-up researchers to continue to collect data from these countries for verification.

\section{Acknowledgements}

This work was supported by Funding Projects for the Introduction of Overseas Talents in Hebei Province (C20210108).

\section{References}

[1] Dong Z, Wei X, Zhang Y. The allocation of entrepreneurial efforts in a rent-seeking society: Evidence from China. J Comp Econ. 2016;44:353-71. DOI: 10.1016/j.jce.2015.02.004.

[2] Baumol WJ. Entrepreneurship: Productive, unproductive, and destructive. J Polit Econ. 1990;98:893-921. Available from: https://www.jstor.org/stable/2937617.

[3] Baumol WJ. Entrepreneurship, Management, and the Structure of Payoffs. Cambridge, MA: MIT Press; 1994. Available from: https://mitpress.mit.edu/books/entrepreneurship-management-and-structure-payoffs.

[4] The Free-Market Innovation Machine. 2004. Available from: https://press.princeton.edu/books/paperback/ 9780691116303/the-free-market-innovation-machine.

[5] Lema R, Johnson B, Andersen AD, Lundvall BA, Chaudhary A. Low-Carbon Innovation and Development. Rochester, NY: Social Science Research Network; 2014. Report No.: ID 2427065. Available from: https://papers.ssrn.com/abstract=2427065.

[6] Żuk O, Kosior G, Oloś G. Characteristics of acute toxicity dynamics of selected toxicants on aquatic crustaceans. Ecol Chem Eng S. 2019;26(2):397-408. DOI: 10.1515/eces-2019-0028.

[7] Saturnino Neto A, José Chiappetta Jabbour C, Beatriz Lopes de Sousa Jabbour A. Green training supporting eco-innovation in three Brazilian companies: practices and levels of integration. Ind Commer Train. 2014;46:387-92. DOI: 10.1108/ICT-02-2014-0010.

[8] Montalvo C, Diaz Lopez FJ, Brandes F. Potential for Eco-innovation in Nine Sectors of the European Economy. 2011. DOI: 10.13140/RG.2.1.3718.6084.

[9] Kim T. Confucianism, Modernities and Knowledge: China, South Korea and Japan. In: Cowen R, Kazamias AM, editors. International Handbook of Comparative Education. Dordrecht: Springer Netherlands; 2009; 857-72. DOI: 10.1007/978-1-4020-6403-6_55.

[10] Gast J, Gundolf K, Cesinger B. Doing business in a green way: A systematic review of the ecological sustainability entrepreneurship literature and future research directions. J Clean Prod. 2017;147:44-56. DOI: 10.1016/j.jclepro.2017.01.065. 
[11] Aldrich H, Martin R. Organizations Evolving. SAGE; 2006. Available from: https://sk.sagepub.com/books/organizations-evolving-2e.

[12] Frye T, Shleifer A. The Invisible Hand and the Grabbing Hand. National Bureau of Economic Research; 1996. Report No.: 5856. Available from: https://www.nber.org/papers/w5856.

[13] Lim DSK, Morse EA, Mitchell RK, Seawright KL. Institutional environment and entrepreneurial cognitions: A comparative business systems perspective. Entrep Theory Pract. 2010;34:491-516. DOI: 10.1111/j.1540-6520.2010.00384.x

[14] OECD. Eco-Innovation in Industry: Enabling Green Growth. Eco-Innov Ind Enabling Green Growth. 2010;1-276. Available from: https://www.oecd.org/sti/ind/ecoinnovationinindustryenablinggreengrowth.htm.

[15] Gerlach A. Sustainable entrepreneurship and innovation. Corp Soc Responsib Environ Manage. 2003;29-30. Available from: https:/fdocuments.in/reader/full/sustainable-entrepreneurship-and-innovation-typeentrepreneurship-andsustainable.

[16] Arundel A, Kemp R. Measuring eco-innovation. UNI-MERIT Res Memo. 2009;2009:1-40. Available from: https://collections.unu.edu/eserv/UNU:869/rb01_08_measuring_eco_innovation.pdf.

[17] Pujari D. Eco-innovation and new product development: understanding the influences on market performance. Technovation. 2006;26:76-85. DOI: 10.1016/j.technovation.2004.07.006.

[18] Halila F, Rundquist J. The development and market success of eco-innovations: A comparative study of eco-innovations and "other" innovations in Sweden. Eur J Innov Manage. 2011;14:278-302. DOI: $10.1108 / 14601061111148807$.

[19] Iyer ES, Reczek RW. The intersection of sustainability, marketing, and public policy: Introduction to the special section on sustainability. J Public Policy Mark. 2017;36:246-54. DOI: 10.1509/jppm.36.250.

[20] Silva DO, Bagno RB, Salerno MS. Models for innovation management: review and analysis of the literature. Production. 2014;24:477-90. DOI: 10.1590/S0103-65132013005000059.

[21] Cagnazzo L, Taticchi P, Botarelli M. A literature review on innovation management tools. Rev Adm Universidade Fed St Maria. 2008;1:316-30. DOI: 10.5902/19834659620.

[22] Hidalgo A, Albors J. Innovation management techniques and tools: a review from theory and practice. RD Manage. 2008;38:113-27. DOI: 10.1111/j.1467-9310.2008.00503.x.

[23] Díaz-García C, González-Moreno Á, Sáez-Martínez FJ. Eco-innovation: insights from a literature review. Innovation. 2015;17:6-23. DOI: 10.1080/14479338.2015.1011060.

[24] Cai W, Li G. The drivers of eco-innovation and its impact on performance: Evidence from China. J Clean Prod. 2018;176:110-8. DOI: 10.1016/j.jclepro.2017.12.109.

[25] Boyd GA, Pang JX. Estimating the linkage between energy efficiency and productivity. Energy Policy. 2000;28:289-96. DOI: 10.1016/S0301-4215(00)00016-1.

[26] Oh M, Shin J, Park PJ, Kim S. Does eco-innovation drive sales and technology investment? Focusing on eco-label in Korea. Bus Strategy Environ. 2020;29:3174-86. DOI: 10.1002/bse.2565.

[27] Loučanová E, Šupín M, Čorejová T, Repková-Štofková K, Šupínová M, Štofková Z, et al. Sustainability and branding: An integrated perspective of eco-innovation and brand. Sustainability. 2021;13:732. DOI: $10.3390 /$ su13020732.

[28] International Organization for Standardization: Geneve (Switzerland). ISO 14006:2011. Environmental management systems - Guidelines for incorporating ecodesign. Available from: https://www.iso.org/cms/render/live/en/sites/isoorg/contents/data/standard/04/32/43241.html.

[29] Hall BH. The financing of research and development. Oxf Rev Econ Policy. 2002;18:35-51. DOI: 10.1093/oxrep/18.1.35.

[30] Hall BH. The Financing of Innovation. The Handbook of Technology and Innovation Management. S. Shane, editor. Oxford: Blackwell Publishers; 2005, 409-30. Available from: https://www.wiley.com/ en-ag/The+Handbook+of+Technology+and+Innovation+Management-p-9781405127912.

[31] Guo L, Long W, Dai Z. Manufacturing R\&D investment efficiency and financing constraints: evidence from $\square$ hina. Appl Econ. 2021;53:676-87. DOI: 10.1080/00036846.2020.1808580.

[32] Savignac F. Impact of financial constraints on innovation: What can be learned from a direct measure? Econ Innov New Technol. 2008;17:553-69. DOI: 10.1080/10438590701538432.

[33] Broome T, Moore W, Alleyne P. Financing constraints and the R\&D decision in the Caribbean. Entrep Reg Dev. 2018;30:964-86. DOI: 10.1080/08985626.2018.1515820.

[34] Yu CH, Wu X, Zhang D, Chen S, Zhao J. Demand for green finance: Resolving financing constraints on green innovation in $\square$ hina. Energy Policy. 2021;153:112255. DOI: 10.1016/j.enpol.2021.112255.

[35] Nanda R, Rhodes-Kropf M. Financing risk and innovation. Manage Sci. 2017;63:901-18. DOI: 10.1287/mnsc.2015.2350. 
The government-business relationship and eco-innovation: evidence from Chinese automobile industry 561

[36] Münzel C, Plötz P, Sprei F, Gnann T. How large is the effect of financial incentives on electric vehicle sales? - A global review and European analysis. Energy Econ. 2019;84:104493. DOI: 10.1016/j.eneco.2019.104493.

[37] Jenn A, Springel K, Gopal AR. Effectiveness of electric vehicle incentives in the United States. Energy Policy. 2018;119:349-56. DOI: 10.1016/j.enpol.2018.04.065.

[38] Kester J, Noel L, de Rubens GZ, Sovacool B. Policy mechanisms to accelerate electric vehicle adoption: a qualitative review from the Nordic region. Renew Sustain Energy Rev. 2018;94:719-31. DOI: 10.1016/j.rser.2018.05.067.

[39] Lai WH, Lin CC, Wang TC. Exploring the interoperability of innovation capability and corporate sustainability. J Bus Res. 2015;68:867-71. DOI: 10.1016/j.jbusres.2014.11.043.

[40] Forcadell FJ, Aracil E, Úbeda F. The influence of innovation on corporate sustainability in the international banking industry. Sustainability. 2019;11:3210. DOI: 10.3390/su11113210.

[41] Jensen MC, Meckling WH. Theory of the firm: Managerial behavior, agency costs and ownership structure. J Financ Econ. 1976;3:305-60. DOI: 10.1016/0304-405X(76)90026-X.

[42] Peng MW, Wang DY, Jiang Y. An institution-based view of international business strategy: A focus on emerging economies. J Int Bus Stud. 2008;39:920-36. DOI: 10.1057/palgrave.jibs.8400377.

[43] RUC National Academy of Development and Strategy. Government-Business Relations Ranking List 2018. Beijing: RUC National Academy of Development and Strategy; 2019. Available from: http://en.nads.ruc.edu.cn/Multimedia/0f8409f1d5b340009a3012dbe518c913.htm.

[44] Zhang D, Rong Z, Ji Q. Green innovation and firm performance: Evidence from listed companies in China. Resour Conserv Recycl. 2019;144:48-55. DOI: 10.1016/j.resconrec.2019.01.023.

[45] Albino V, Ardito L, Dangelico RM, Messeni Petruzzelli M. Understanding the development trends of low-carbon energy technologies: A patent analysis. Appl Energy. 2014;135:836-54. DOI: 10.1016/j.apenergy.2014.08.012.

[46] Wu Y, Gu F, Ji Y, Guo J, Fan Y. Technological capability, eco-innovation performance, and cooperative R\&D strategy in new energy vehicle industry: Evidence from listed companies in China. J Clean Prod. 2020;261:121157. DOI: 10.1016/j.jclepro.2020.121157.

[47] Gotti G, Han S, Higgs JL, Kang T. Managerial stock ownership, analyst coverage, and audit fee. J Account Audit Finance. 2012;27:412-37. DOI: 0.1177/0148558X11409158.

[48] Shen H, Hou F. Trade policy uncertainty and corporate innovation evidence from Chinese listed firms in new energy vehicle industry. Energy Econ. 2021;97:105217. DOI: 10.1016/j.eneco.2021.105217.

[49] Chan K, Wang J, Wei KCJ. Underpricing and long-term performance of IPOs in China. J Corp Finance. 2004;10:409-30. DOI: 10.1016/S0929-1199(03)00023-3.

[50] Guan KL. Will the intimate and clean relationship between politics and business affect corporate innovations? Empirical evidences from China's listed companies. Contemp Finance Econ. 2019;2019:130-41. Available from: http://cfejxufe.magtech.com.cn/ddcj/EN/Y2019/V0/I06/1827.

[51] Hadlock CJ, Pierce JR. New evidence on measuring financial constraints: Moving beyond the KZ Index. Rev Financ Stud. 2010;23:1909-40. DOI: 10.1093/rfs/hhq009.

[52] Wen F, Li C, Sha H, Shao L. How does economic policy uncertainty affect corporate risk-taking? Evidence from China. Finance Res Lett. 2021;41:101840. DOI: 10.1016/j.frl.2020.101840.

[53] Baron RM, Kenny DA. The moderator-mediator variable distinction in social psychological research: conceptual, strategic, and statistical considerations. J Pers Soc Psychol. 1986;51:1173-82. DOI: 10.1037//0022-3514.51.6.1173.

[54] Wen ZL, Ye BJ. Analyses of mediating effects: The development of methods and models. Adv Psychol Sci. 2014;22:731-45. DOI: 10.3724/SP.J.1042.2014.00731.

[55] Gao Y, Han KS. Managerial overconfidence, CSR and firm value. Asia-Pac J Account Econ. 2020;1-19. DOI: $10.1080 / 16081625.2020 .1830558$.

[56] Sołowski G, Konkol I, Cenian A. Perspectives of hydrogen production from corn wastes in Poland by means of dark fermentation. Ecol Chem Eng S. 2019;26(2):255-63. DOI: 10.1515/eces-2019-0031.

[57] Hamilton GG, Biggart NW. Market, culture, and authority: A comparative analysis of management and organization in the Far East. Am J Sociol. 1988;94:S52-94. Available from: https://www.jstor.org/stable/2780242. 